\title{
Seasonal Carbonate Chemistry
} Dynamics on Southeast Florida Coral Reefs: Localized Acidification Hotspots From Navigational Inlets

\section{OPEN ACCESS}

Edited by:

Tyler Cyronak,

Scripps Institution of Oceanography,

University of California, San Diego,

United States

Reviewed by:

Coulson Lantz,

Southern Cross University, Australia

Yuri Artioli,

Plymouth Marine Laboratory,

United Kingdom

Yuichiro Takeshita,

Monterey Bay Aquarium Research

Institute (MBARI), United States

*Correspondence: Ian C. Enochs

ian.enochs@noaa.gov

Specialty section:

This article was submitted to Global Change and the Future Ocean,

a section of the journal Frontiers in Marine Science

Received: 01 November 2018 Accepted: 14 March 2019 Published: 10 April 2019

Citation: Enochs IC, Manzello DP, Jones PR Stamates SJ and Carsey TP (2019)

Seasonal Carbonate Chemistry Dynamics on Southeast Florida Coral

Reefs: Localized Acidification Hotspots From Navigational Inlets.

Front. Mar. Sci. 6:160.

doi: 10.3389/fmars.2019.00160

\author{
Ian C. Enochs ${ }^{1 *}$, Derek P. Manzello ${ }^{1}$, Paul R. Jones ${ }^{1,2}$, S. Jack Stamates ${ }^{1}$ and \\ Thomas P. Carsey ${ }^{1}$
}

${ }^{1}$ NOAA, Atlantic Oceanographic and Meteorological Laboratory, Ocean Chemistry and Ecosystem Division, Miami, FL, United States, ${ }^{2}$ Cooperative Institute for Marine and Atmospheric Studies, University of Miami, Miami, FL, United States

Seawater carbonate chemistry varies across temporal and spatial scales. Shallow-water environments can exhibit especially dynamic fluctuations as biological and physical processes operate on a smaller water volume relative to open ocean environments. Water was collected on a bi-monthly basis from seven sites off of southeast Florida (MiamiDade and Broward counties), including four reefs, and three closely-associated inlets. Significant seasonal fluctuations in carbonate chemistry were observed on reef sites, with elevated $\mathrm{pCO}_{2}$ in the warmer wet season. Inlets demonstrated a more dynamic range, with periodic pulses of acidified water contributing to, on average, more advanced acidification conditions than those found at nearby reefs. Within inlet environments, there was a significant negative correlation between seawater salinity and both total alkalinity (TA) and dissolved inorganic carbon (DIC), which was in contrast to the patterns observed on reefs. Elevated TA and DIC in low salinity waters likely reflect carbonate dissolution as a result of organic matter decomposition. Together, these data highlight the important role that inlets play on shallow-water carbonate chemistry dynamics within southeast Florida waters and underscore the degree to which engineered freshwater systems can contribute to coastal acidification on localized scales.

Keywords: ocean acidification, inlet, Port Everglades, Port of Miami, coral reef, SEFCRI

\section{INTRODUCTION}

Roughly $25 \%$ of anthropogenic carbon dioxide production is absorbed by seawater on an annual basis (Le Quéré et al., 2018), contributing to a global decline in $\mathrm{pH}$ known as ocean acidification or OA (Bates et al., 2014). This trend has important implications for the biology of marine organisms and has the potential to lead to large-scale shifts in ecosystem structure and function (Fabry et al., 2008; Enochs et al., 2015).

While patterns in OA are clear in the open ocean, data from near-shore and shallowwater environments are comparatively more complex (Hofmann et al., 2011). Smaller water volumes coupled with the biological activity of benthic communities can lead to alteration of seawater carbonate chemistry via respiration and photosynthesis, as well as calcification and dissolution. The effects of these processes can be further exacerbated by restricted flow and long residence times. Temporal variation in biological processes, such as diel fluctuations in photosynthesis and light-enhanced calcification alter seawater $\mathrm{pH}$ (Price et al., 2012). Seasonal variation in these biological processes 
can also manifest in the overlying waters (Shaw and McNeil, 2014). Additionally, comparatively brief storm events (Manzello et al., 2013) and upwelling (Manzello, 2010) impact and further obscure long-term trends in shallow-water acidification.

Natural variation in benthic community structure, across spatial scales ranging several orders of magnitude ( $\mathrm{cm}$ to $\mathrm{km}$ ), has been closely tied to changes in carbonate parameters. For example, various microhabitats within a reef environment such as filamentous algal gardens may locally elevate $\mathrm{pH}$ (Gagliano et al., 2010). Over larger scales $(\sim 30 \mathrm{~m}), \mathrm{pH}$ has been found to vary between reef zones, distance from shore, and depth within the same reef structure (Silbiger et al., 2014). Still larger-scale variation in the distribution of reef and seagrass habitats can lead to regional and shelf-scale variability on the order of 10's of kilometers (Manzello et al., 2012).

Abiotic processes may also influence seawater carbonate chemistry in shallow-water environments. Volcanic gas vents can locally enhance $\mathrm{CO}_{2}$ concentration (Fabricius et al., 2011) and submarine freshwater seeps (Ojos; Crook et al., 2011) have been shown to lower seawater $\mathrm{pH}$. Upwelling of deep $\mathrm{CO}_{2}$-rich waters can drive periodic regional acidification (Feely et al., 2008; Manzello, 2010). Finally, freshwater systems can strongly impact the carbonate chemistry of adjacent marine ecosystems, either directly due to their export of inorganic carbon, or indirectly via perturbations (e.g., nutrients, organic carbon) that influence carbonate-chemistry-altering biota (Aufdenkampe et al., 2011; Duarte et al., 2013).

While a global rises in atmospheric $\mathrm{CO}_{2}$ is an important driver of $\mathrm{OA}$, it is not the only anthropogenic process contributing to coastal acidification (Duarte et al., 2013). The impact of human activities on both riverine and groundwater systems can lead to downstream effects for estuarine and coastal ecosystems. Eutrophication, for example, can lead to more rapid shifts in carbonate chemistry than global OA processes (Duarte et al., 2013). Algal blooms as the result of nutrient pollution can potentially offset the influences of OA (Borges and Gypens, 2010) but subsequent microbial breakdown of organic matter can lead to elevated $\mathrm{CO}_{2}$ and hypoxia via increased respiration (Cai et al., 2011; Wallace et al., 2014). Highly eutrophied waters can therefore periodically experience $\mathrm{pH}$ values expected to occur at advanced states of global OA (Wallace et al., 2014), and given that their $\mathrm{CO}_{2}$ buffering capacity is already compromised, may be more susceptible to future OA stress (Cai et al., 2011). In addition to eutrophication, agricultural practices and mining have been found to influence carbonate chemistry (Brake et al., 2001; Raymond and Cole, 2003; Oh and Raymond, 2006; Barnes and Raymond, 2009). Ultimately, urbanized watersheds have also been found to contribute twice as much DIC as agricultural areas and nearly eight times as much as those that are naturally forested, owing to elevated $\mathrm{CO}_{2}$ production, along with increased weathering and organic matter contributions from septic and sewer sources (Barnes and Raymond, 2009). Together, these processes demonstrate the close relationship between human activity and the localized perturbation of carbonate chemistry.

The southeast Florida continental reef tract extends from south Miami $\left(25^{\circ} 34^{\prime}\right), \sim 125 \mathrm{~km}$ north to West Palm Beach $\left(26^{\circ} 43^{\prime}\right)$ and is situated in close proximity to dense urban populations, with a heavily engineered system of canals and waterways (Banks et al., 2008). This high-latitude reef system is no longer actively accreting, but exist as a series of three parallel ridges which ceased upward growth between 3,700 and 8,000 years ago (Banks et al., 2007). Acroporid corals, important reefbuilders in the Caribbean, were common as far north as Palm Beach County up until 6,000 years ago (Lighty et al., 1978). The range of these thermally sensitive species contracted south of Miami thereafter, likely due to climatic cooling at this time (Precht and Aronson, 2004). Less thermally sensitive species of coral continued to accrete on the middle reef until 3,700 years ago (Banks et al., 2007). It is still unclear what led to the termination of reef growth at this time; it has been suggested that seasonal cold fronts, elevated turbidity associated with flooding of the Florida shelf, and/or sea-level rise may have led to the cessation of accretion (Lighty et al., 1978; Banks et al., 2007). Hard bottom remains mostly uncolonized, though benthic communities are composed primarily of macroalgae, soft corals, and sponges (Moyer et al., 2003; Banks et al., 2008). Overall coral cover is low $(<6 \%)$, comprised primarily of small colonies, that are depauperate in nature (27 species) compared with the Florida Keys and wider Caribbean (Goldberg, 1973; Moyer et al., 2003).

Three main navigational inlets, man-made marine passageways, influence the area from Miami to Ft. Lauderdale. The Port of Miami Inlet in the southern part of the region connects Biscayne Bay to the open ocean and is highly trafficked by large commercial vessels as well as recreational boat traffics (Figure 1). Baker's Haulover Inlet is located $\sim 15 \mathrm{~km}$ north and provides passage strictly for small vessels through the northern part of Biscayne Bay. Finally, the Port Everglades Inlet is located off of Ft. Lauderdale, $\sim 21 \mathrm{~km}$ further north. Like the Port of Miami, Port Everglades accommodates large commercial shipping vessels.

There is a long history of these inlets influencing the adjacent ocean water, reefs, and corals. For instance, skeletal records from massive corals in the region reveal a 30 year period of low extension, high density growth from 1940 to 1970, which correlates with canal construction and increased freshwater output (Banks et al., 2008). More recently (late 2013-early 2015), dredging activity, conducted to enlarge the Port of Miami for Panamax ships, was associated with large turbidity plumes (127$228 \mathrm{~km}^{2}$ ) that encompassed $\sim 11 \mathrm{~km}^{2}$ of coral habitat in the surrounding waters (Barnes et al., 2015; Miller et al., 2016).

Despite these anthropogenic stressors, southeast Florida coral reefs remain highly utilized for fishing and diving. In a year spanning 2000-2001, they generated 2.1 and 1.3 billion dollars in sales in Broward and Miami-Dade counties, respectively (Johns et al., 2003). As such, these coral reefs represent economically valuable ecosystems, closely associated with dense urban development and heavily engineered waterways. For these reasons, they have been specially targeted for monitoring and management through the Southeast Florida Coral Reef Initiative (SEFCRI). The goal of this study is to describe the temporal and spatial variability of carbonate chemistry of this region, both as a present-day baseline for future monitoring efforts, as well as a means of preliminarily investigating the magnitude of localized anthropogenic acidification. 


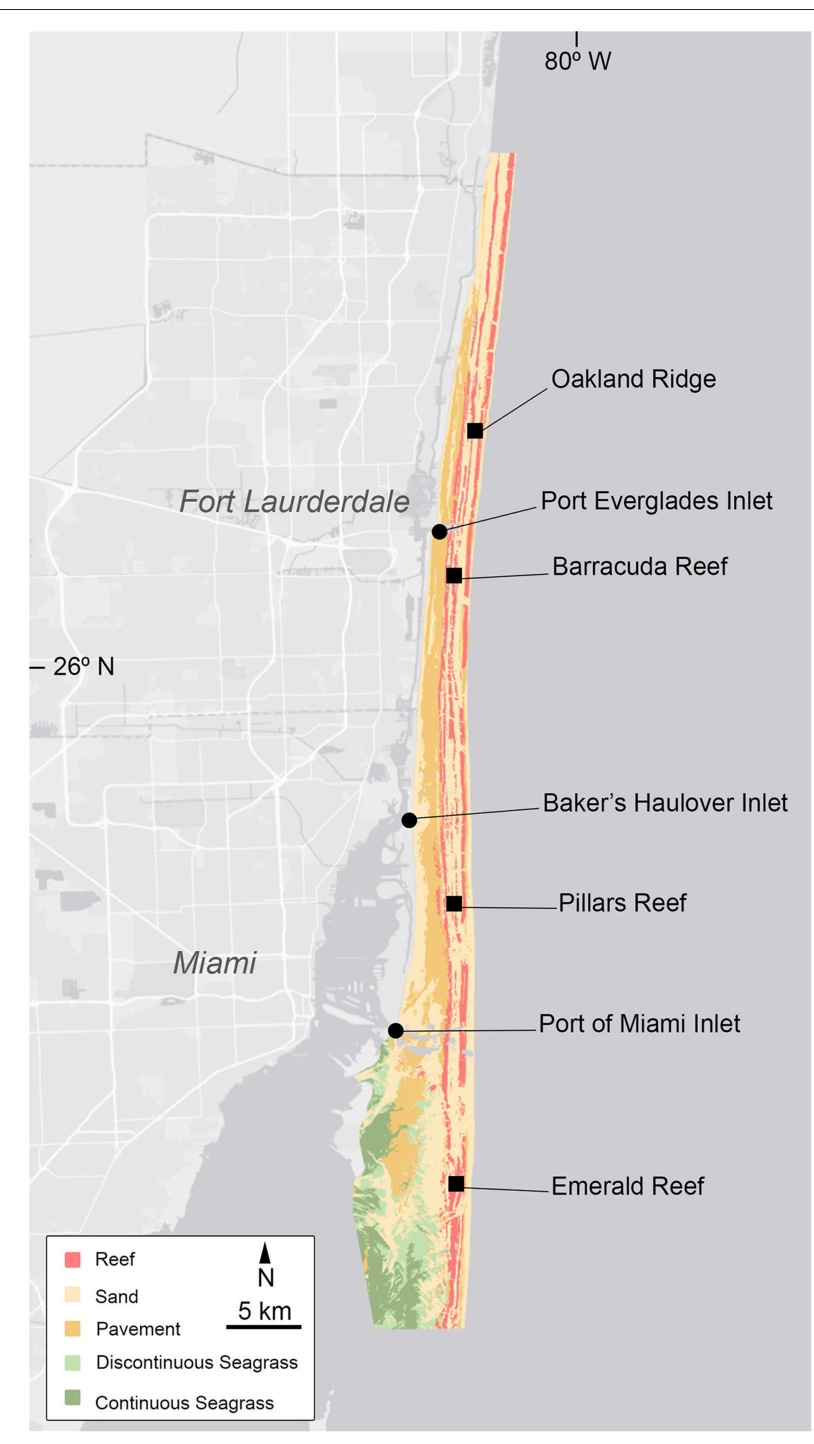

FIGURE 1 | Site map showing the four reef (squares) and three inlets (circles) sampling sites. Colors reflect the dominant benthic habitat type. GIS data obtained from Florida Fish and Wildlife Research Institute (FWRI). http:// research.myfwc.com.

\section{MATERIALS AND METHODS}

Four reefs (Oakland Ridge, Barracuda, Pillars, and Emerald) and three inlets (Port Everglades, Bakers Haulover, and Port of Miami) were selected, spanning Miami-Dade and Broward Counties (Figure 1). Three replicate sampling sites were selected per reef, while a single sampling location was selected per inlet. Seawater samples were collected at each site on a bi-monthly basis from May 2014 to September 2015. Southeast Florida experiences a warm wet season from late May to October, and a cooler dry season from late October to early May. For analysis, data were binned by season and depth. All were collected between the hours of 8:11 and 14:31 and those collected in the vicinity of inlets were timed to occur during outgoing tides, though tidal range in the region is less than a meter.
Water samples were collected from the surface ( $\sim 1 \mathrm{~m}$ depth) and immediately above the benthos (10.3-17.6 $\mathrm{m}$ depth, except Baker's Haulover) using a rosette sampler (ECO 55, Seabird). Temperature was recorded at each depth using a CTD (SBE 19V2, Seabird). Turbidity (NTU) was measured at the time of water collection using 90 degree infrared backscatter (Turner Designs). Once collected, water samples were transferred to borosilicate glass jars while minimizing turbulent water movement, bubbles, and gas exchange. Samples were fixed using $200 \mu \mathrm{L}$ of $\mathrm{HgCl}_{2}$, sealed using Apiezon grease and a ground glass stopper. Salinity was measured using a densitometer (DMA 5000M, Anton Paar). Total alkalinity (TA) was determined using automated Gran titration using an AS-ALK2 (Apollo SciTech). Dissolved inorganic carbon (DIC) was measured using an AS-C3 (Apollo SciTech) and a LI-7000 non-dispersive infrared $\mathrm{CO}_{2}$ analyzer (LI-COR). Both TA and DIC values were measured in duplicate and corrected using certified reference materials following recommendations in Dickson et al. (2007). Aragonite saturation state $\left(\Omega_{\text {Arag. }}\right), \mathrm{pH}$ (Total scale), and the partial pressure of $\mathrm{CO}_{2}$ $\left(\mathrm{pCO}_{2}\right)$ were calculated with CO2SYS (Lewis and Wallace, 1998) using the dissociation constants of Mehrbach et al. (1973) as refit by Dickson and Millero (1987) and Dickson (1990).

Water samples were reserved for nutrient analysis at the time of collection. Total Kjeldahl nitrogen (TKN) and total phosphorous (TP), were determined by semi-automated colorimetry (Methods 351.2 rev. 2, 365.1 rev. 2; EPA, 1993a,b TKN and TP, respectively). Chlorophyll- $a$ was determined through fluorescence (Method 445.0 rev. 1.2, EPA, 1997). Analyses of TP, TKN and Chlorophyll- $a$ were performed by the Florida Department of Environmental Protection (FDEP, Tallahassee, Florida).

Normalization of TA and DIC to a constant salinity (35) followed the recommendations of Friis et al. (2003) for normalization to a non-zero end member, which were determined using linear regression of sample data. Temperature, salinity, and carbonate chemistry data at each site were analyzed for normality and homoscedasticity using Shapiro-Wilk and Levene's tests, respectively. Data which did not conform to the assumptions of a parametric analysis were analyzed using a Kruskal-Wallis test, while all others were analyzed using a one way ANOVA, with unique combinations of season and depth as factors (e.g., dry shallow, dry deep, wet shallow, wet deep). Data were pooled across sites in order to compare conditions present at reefs vs. inlets. Non-parametric Wilcox signed-rank tests were performed to determine the significance of these differences. All statistical analyses were performed using $\mathrm{R}$ and $\mathrm{R}$ Studio (R Team, 2008; RStudio Team, 2015). All data are publicly available through NOAA's National Centers for Environmental Information (NCEI, https://www.nodc.noaa.gov/archivesearch/, accession 0185741).

\section{RESULTS}

\section{Reef Water Chemistry}

Averaged across depths and sites, temperature was higher in the wet $28.7 \pm 1.26^{\circ} \mathrm{C}($ mean $\pm \mathrm{SD})$ vs. the dry season $25.1 \pm 1.33^{\circ} \mathrm{C}$ (Table 1; Table S1; Figure 2). No significant seasonal fluctuations 
TABLE 1 | Environmental conditions and sample sizes at four reef and three inlet sites off of southeast Florida.

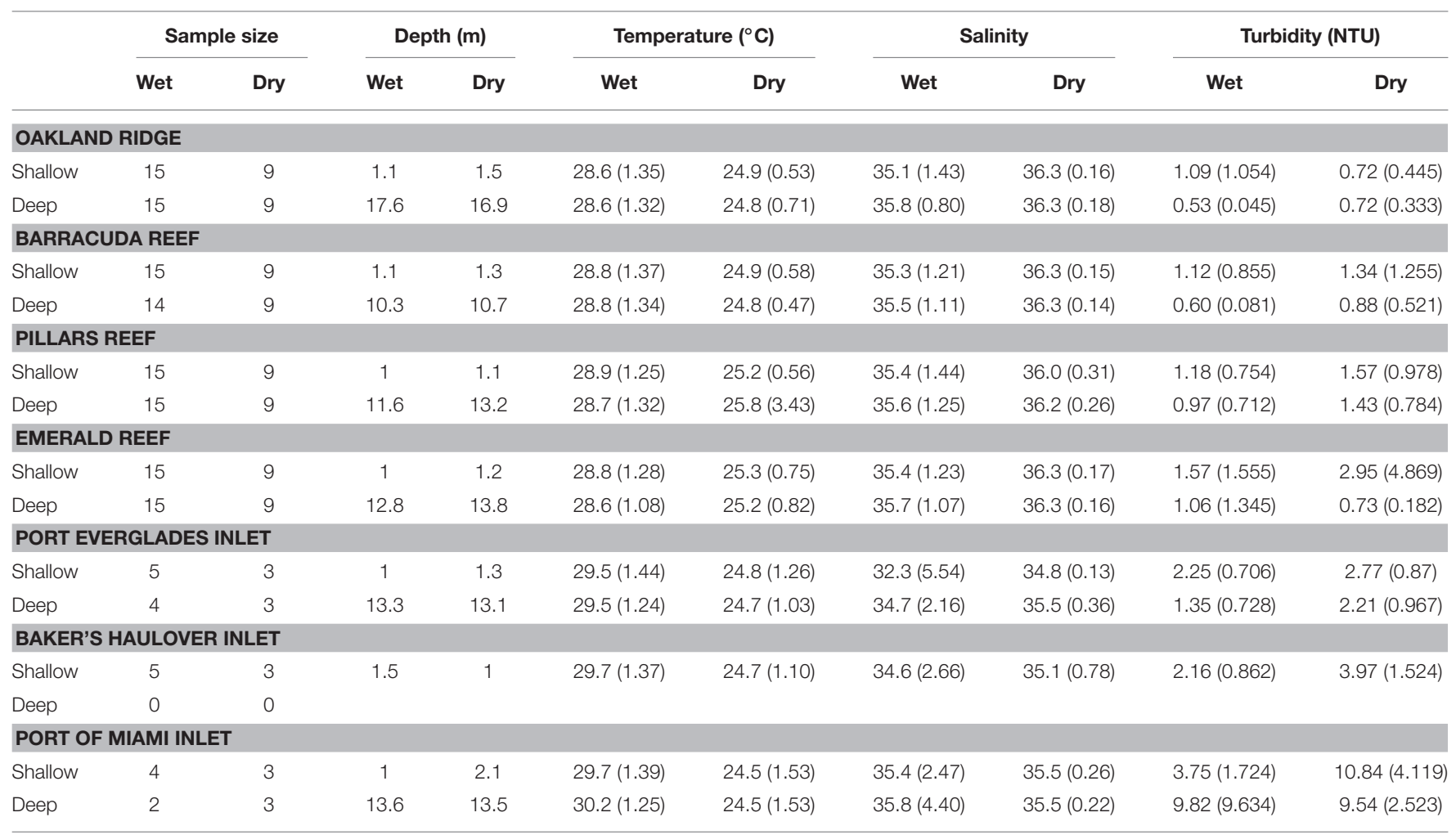

Values are means ( \pm Std. Dev.) and are arranged according to season (Wet and Dry) as well as for two depth bins (Shallow and Deep).

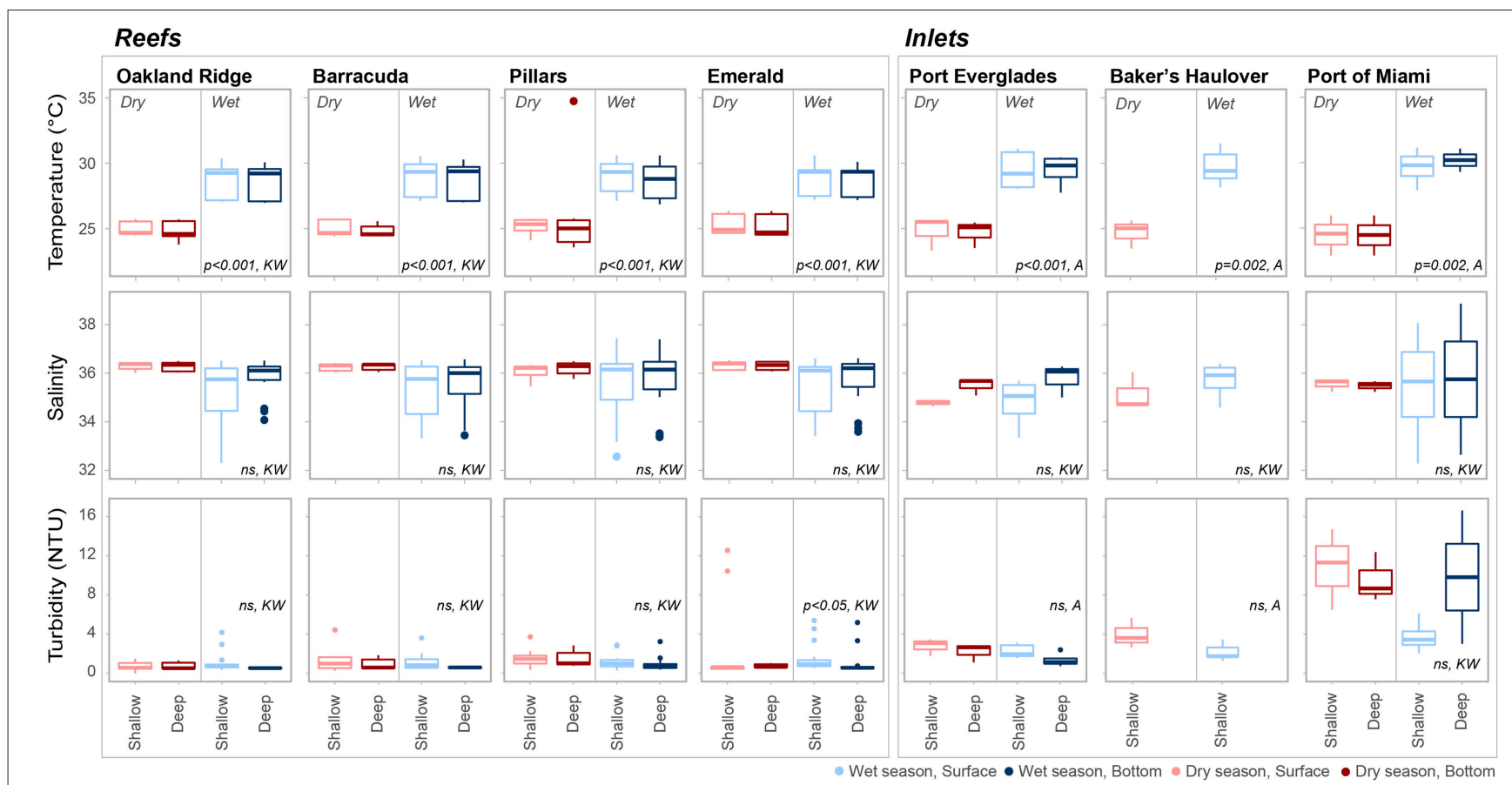

FIGURE 2 | Temperature $\left({ }^{\circ} \mathrm{C}\right.$ ), salinity, and turbidity (NTU) at each of four reef and three inlet sampling sites. Data are divided into dry (red) and wet season (blue). Darker colors represent samples taken above the benthos while lighter colors represent samples taken at the surface. $P$ values are given for significant differences as determined by ANOVA (A) or nonparametric Kruskal-Wallis (KW) tests. Non-significant $(p>0.05)$ are marked ns. 
in salinity were detected within reef sites (Table S1; Figure 2), though averaged across all reef sites salinity was higher in the dry $36.25 \pm 0.209$, vs. the more variable wet season $(35.48 \pm 1.192$, Table 1; Figure 2). Significant seasonal fluctuation in turbidity was only detected at the southern-most reef site (Emerald), which displayed extreme high-turbidity outliers that were present to a lesser extent at other reef sites (Table 1; Table S1; Figure 2).

There were significant seasonal fluctuations in temperature, TA, and DIC at reef sites (Table 2; Table S2; Figures 3, 4). No clear trends were distinguishable between samples collected at the surface and those collected at depth. On average, the dry season was characterized by higher TA $(2,384.3 \pm 9.24$ vs. $2,368.89$ $\left.\mu \mathrm{mol} \mathrm{kg}{ }^{-1}\right)$ and DIC $(2,059.2 \pm 18.05$ vs. $2,041.6 \pm 19.71 \mu \mathrm{mol}$ $\left.\mathrm{kg}^{-1}\right)$. TA and DIC were both positively correlated with salinity at reef sites, with zero salinity end members of 2,137.1 $\mu \mathrm{mol} \mathrm{kg}-1$ and $1,864.8 \mu \mathrm{mol} \mathrm{kg}^{-1}$, respectively (Figure 5). The fit of these relationships, however, are low $\left(R^{2}=0.215\right.$ and 0.058 , TA and DIC, respectively) and predicted end members should therefore be treated with a degree of caution.

Seasonal variability of calculated carbonate chemistry parameters was more nuanced than that of TA and DIC (Table 2; Table S2; Figure 6). All reefs with the exception of Pillars had higher $\mathrm{pCO}_{2}$ in the wet season, corresponding to a lower pH (Table 2; Table S2; Figure 6). Counterintuitively, the acidified wet-season waters at Oakland and Barracuda (as well as Pillars) had high $\Omega_{\text {Arag. }}$, which may be an effect of the elevated temperature (Tables 1, 2; Tables S1, S2; Figure 6). Significant differences in nutrients across depths and seasons were only observed at Oakland, Barracuda, and Pillars reefs, which had higher TP in the dry season (Tables S3, S4; Figure S2).

Salinity normalized TA-DIC plots yielded significant linear relationships at Oakland and Pillars (Figure 7). Relationships were not significant at Barracuda and Emerald, which had a small range of salinity normalized DIC (nDIC) than the aforementioned reef sites. The slope of the nTA/nDIC line, was only slightly higher at Pillars (0.547) than Oakland Ridge (0.447).

\section{Inlet Fluctuations}

As with reef sites, temperature was significantly higher in the wet season and no clear stratification with depth was detected (Table 1; Table S1; Figure 2) The wet season resulted in more variable salinity at inlet sites (Table 1; Figures 2, 5), though no significant differences were detected across depths and seasons (Table S1; Figure 2). While intra-site seasonal variation in turbidity was not significant, Port of Miami had much higher, and more variable turbidity compared with Port Everglades or Baker's Haulover (Figure 2).

Both TA $\left(R^{2}=0.665, P<0.001\right)$ and DIC $\left(R^{2}=0.678\right.$, $P<0.001)$ were strongly negatively correlated with salinity at inlet sites, reflecting contributions from terrestrial freshwater sources (Figure 5). Across all considered inlets, the extremes in salinity (Table 1; Figure 2) experienced during the wet seasons were accompanied by the most extreme TA and DIC (Table 2; Figures 3-5). While there was a general trend of higher TA during the dry season, significant differences were only detected at Port Everglades (Table S2; Figure 3). The same site revealed strong depth stratification in TA, and to a lesser extent DIC, with higher values observed in surface waters (Table 2; Figures 4,
5). These surface waters were generally less saline than those from the deep, though no significant differences were detected (Table 1; Table S1; Figure 2). No significant differences in DIC were detected between depth/season groupings at any of the inlet sites (Table S2).

Unlike many of the reef sites, which displayed strong seasonal fluctuations in mean $\mathrm{pCO}_{2}, \mathrm{pH}$, and $\Omega_{\text {Arag. }}$, no significant trends were detected in the calculated carbonate chemistry parameters (Table S2; Figure 6). This was largely due to much higher variability (Table 2; Figure 6) displayed in these parameters at the inlet sites. Extreme highs in $\mathrm{pCO}_{2}$, accompanied by low $\mathrm{pH}$, were especially apparent in surface waters during the wet season in Port Everglades (Figure 6). No significant seasonal/depth patterns were observed in TKN, TP, or Chlorophyll- $a$ at inlet sites (Tables S3, S4; Figure S2).

Significant linear relationships between salinity-normalized nTA and nDIC were observed at the two larger Inlets (Port Everglades and Port of Miami) but not at Baker's Haulover (Figure 7). This may have been a function of sample size, as Baker's Haulover only included surface samples. Port of Miami had the highest slope (0.774) of all measured sites including reefs, while Port Everglades had the lowest (0.353).

\section{Inlet vs. Reef Sites}

Salinity was significantly lower $(P<0.0001, \mathrm{~W}=1,867.5)$ at inlet $(34.7 \pm 2.67$, mean $\pm \mathrm{SD})$ vs. reef sites $(35.8 \pm 1.02)$ but there was no significant difference detected in temperature $(P$ $=0.6167)$. All carbonate chemistry parameters were found to be significantly different $\left(P<0.0001, \mathrm{~W}_{\mathrm{TA}}=5,317, \mathrm{~W}_{\mathrm{DIC}}=\right.$ $\left.5,424, \mathrm{~W}_{\mathrm{pH}}=5,376, \mathrm{~W}_{\mathrm{pCO} 2}=1,436, \mathrm{~W}_{\Omega \text { Arag. }}=1,104.5\right)$ between site types. Both TA $(2,425.6 \pm 76.97$ vs. $2,474.7 \pm 14.44 \mu \mathrm{mol}$ $\mathrm{kg}^{-1}$, inlets vs. reefs, respectively) and DIC (2,137.0 $\pm 107.10 \mathrm{vs.}$ $2,048.3 \pm 20.89 \mu \mathrm{mol} \mathrm{kg}{ }^{-1}$ ) were higher at inlets vs. reef sites. These contributed to an elevated $\mathrm{pCO}_{2}$, lower $\mathrm{pH}$, and depressed $\Omega_{\text {Arag. }}$ at inlet sites vs. reefs. TKN $(P<0.0001, \mathrm{~W}=5,241)$, TP $(P<0.0001, \mathrm{~W}=5,735)$, and Chlorophyll- $a(P<0.0001, \mathrm{~W}=$ $6,158)$ were all higher at inlet vs. reef sites $(6.84 \pm 4.34$ vs. $4.00 \pm$ $1.90 \mu \mathrm{M}$ TKN; $0.34 \pm 0.14$ vs. $0.25 \pm 0.19 \mu \mathrm{M} \mathrm{TP} ; 1.33 \pm 0.65$ vs. $0.42 \pm 0.28 \mu \mathrm{g} \mathrm{L}^{-1}$ Chlorophyll-a).

\section{DISCUSSION}

Carbonate chemistry parameters at reef sites and seasonal variation thereof are consistent with those reported from offshore reef sites in the Florida Keys (Manzello et al., 2012). Seasonal variability in $\mathrm{pCO}_{2}$, however, was in line with that reported at offshore stations (Bermuda, Bates, 2007) and it is possible that fluctuations observed on reefs were due to largescale open ocean processes. Benthic marine organisms and water chemistry are strongly interdependent and spatial variation in community composition can impact the carbonate chemistry of associated waters. For example, regions with high seagrass biomass such as inshore patch reefs of the Upper Florida Keys may exhibit net $\mathrm{CO}_{2}$ sequestration, locally elevating saturation states and providing refugia for calcifying organisms such as corals (Manzello et al., 2012). Despite the prevalence of seagrass within nearby Biscayne Bay (Figure 1, Lirman and Cropper, 


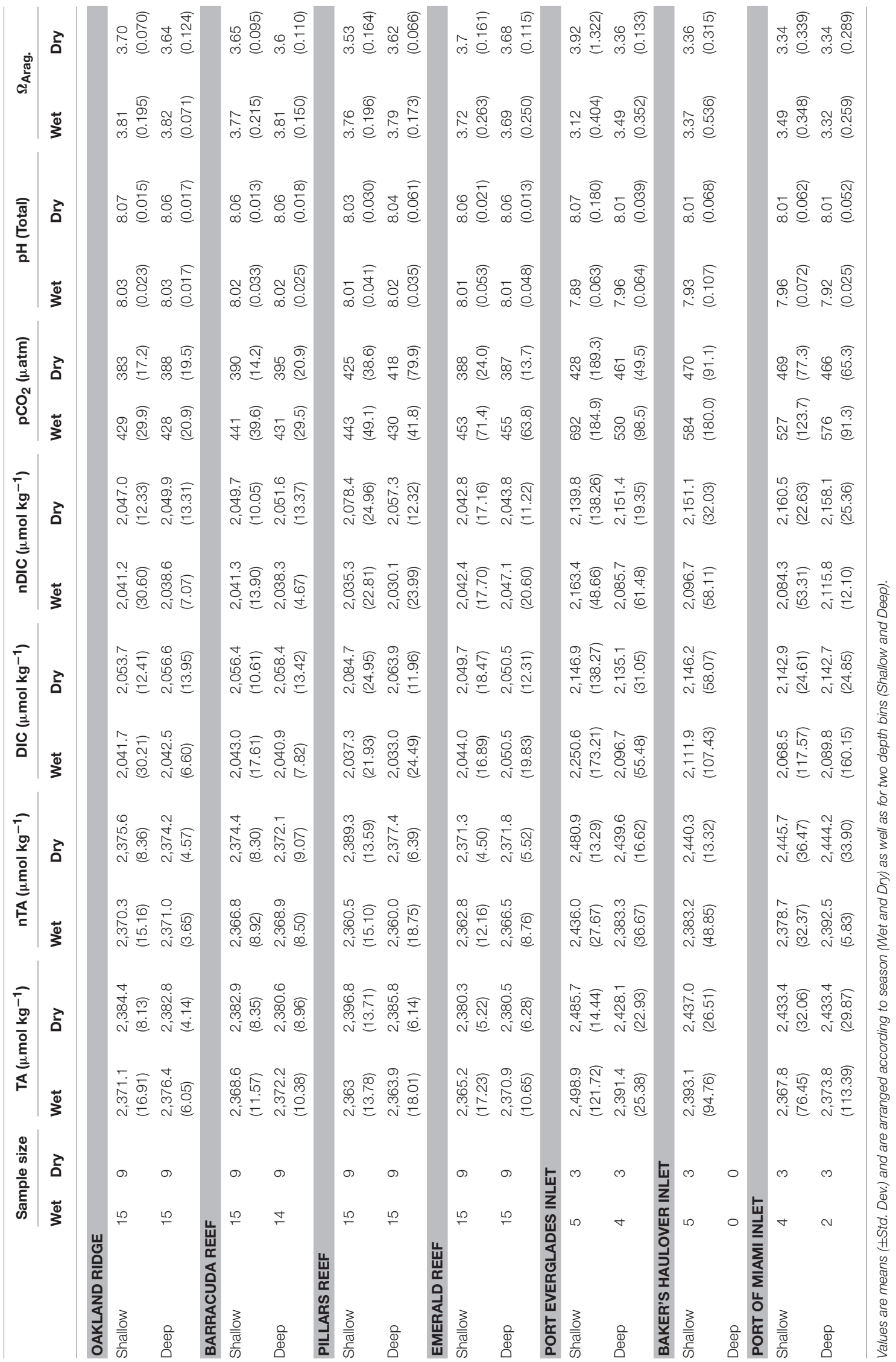




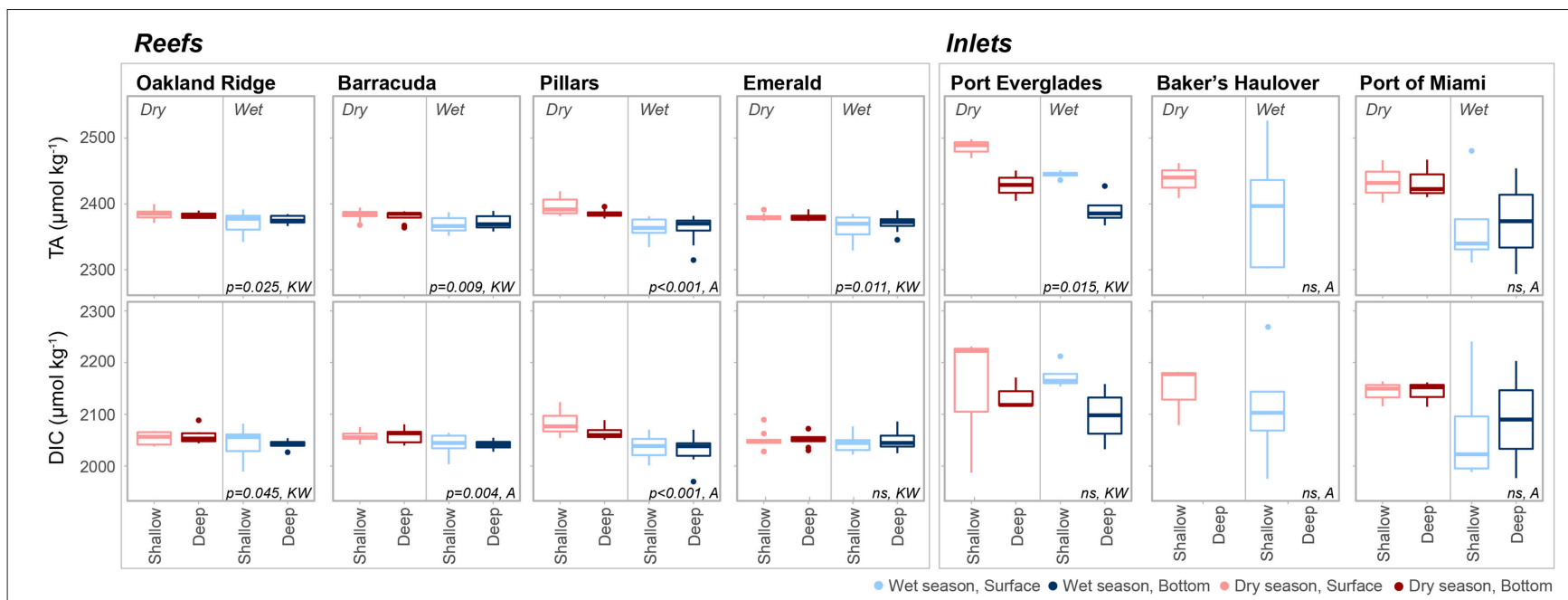

FIGURE 3 | Total alkalinity (TA, $\mu \mathrm{mol} \mathrm{kg}{ }^{-1}$ ) and dissolved inorganic carbon (DIC, $\mu \mathrm{mol} \mathrm{kg}^{-1}$ ) at each of four reef and three inlet sampling sites. Data are divided into dry (red) and wet season (blue). Darker colors represent samples taken above the benthos while lighter colors represent samples taken at the surface. $P$ values are given for significant differences as determined by ANOVA (A) or nonparametric Kruskal-Wallis (KW) tests. Non-significant ( $p>0.05$ ) are marked ns. An outlier surface sample $\left(2,716.5,2,557.8 \mu \mathrm{mol} \mathrm{kg}{ }^{-1}\right.$, TA and DIC, respectively) from Port Everglades collected in September 2014 is not shown in order to be better visualize the dataset.

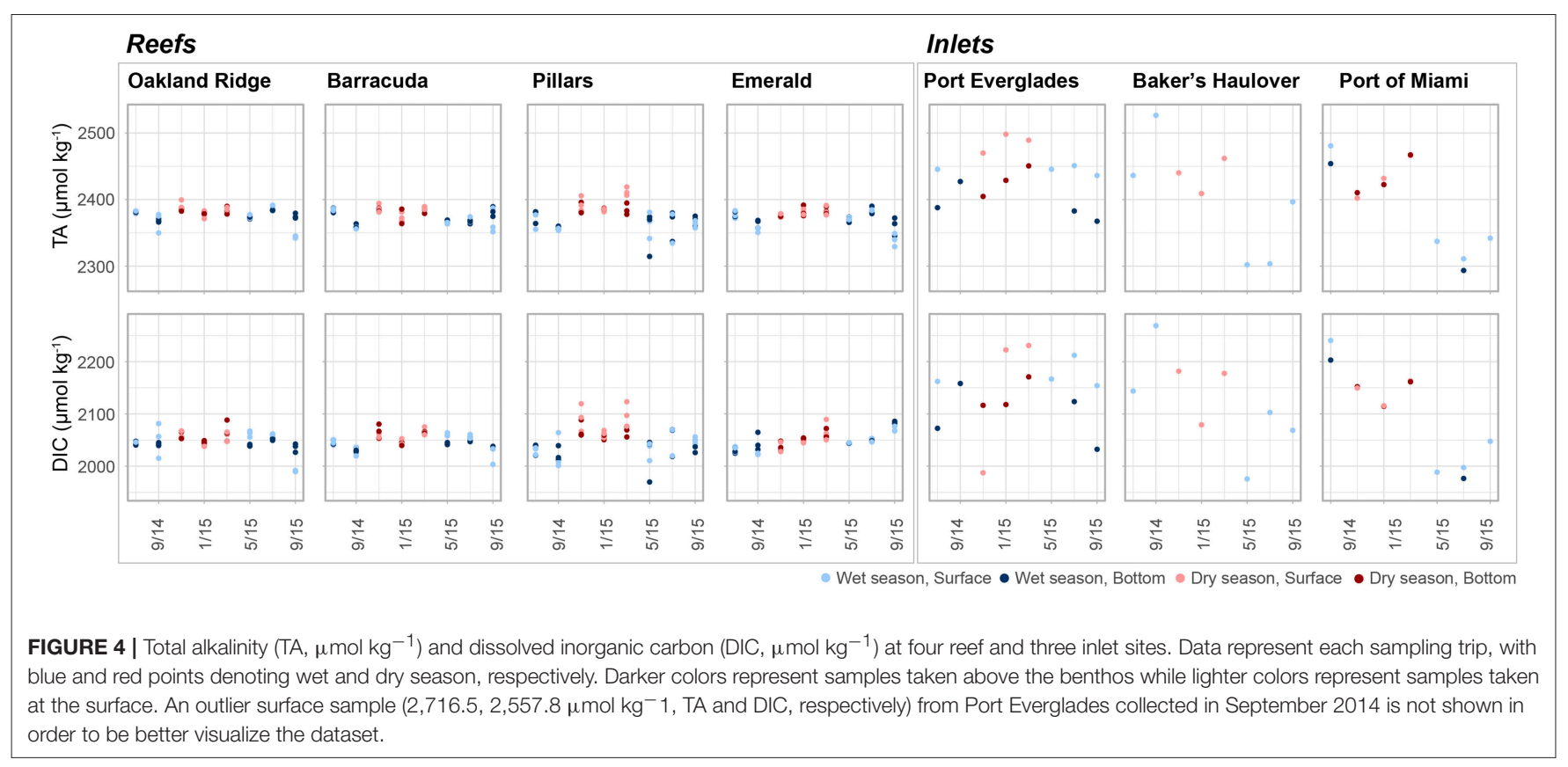

2003), Emerald Reef did not appear to demonstrate the OArefugium characteristics of inshore Upper Keys reefs (Manzello et al., 2012). The slope (when significant) of nTA/nDIC plots of water from reef sites ranged from 0.447 to 0.547 (Figure 7), reflecting the importance of calcification/dissolution at these sites relative to photosynthesis/respiration (Lantz et al., 2013). Relative to open ocean endmembers for TA in the nearby Florida Keys (2,377 $\mu \mathrm{mol} \mathrm{kg}{ }^{-1}$, Cyronak et al., 2018) reefs were not strongly skewed toward net calcification or dissolution, though Pillars Reef does appear to favor calcification in the wet vs. dry season (Figure 7; Table 2). These slopes and the importance of calcification/dissolution are interesting considering the low coral cover and high benthic algae prevalence on reefs in this region (Moyer et al., 2003; Banks et al., 2008).

Within southeast Florida, inlets (especially Port of Miami and Port Everglades) act as acidification hotspots. There was a significant negative relationship between both DIC and TA with salinity, as DIC and TA were elevated at the inlets despite depressed salinity (Figure 5). The increase in DIC was disproportionately higher than the increase in TA, which led 


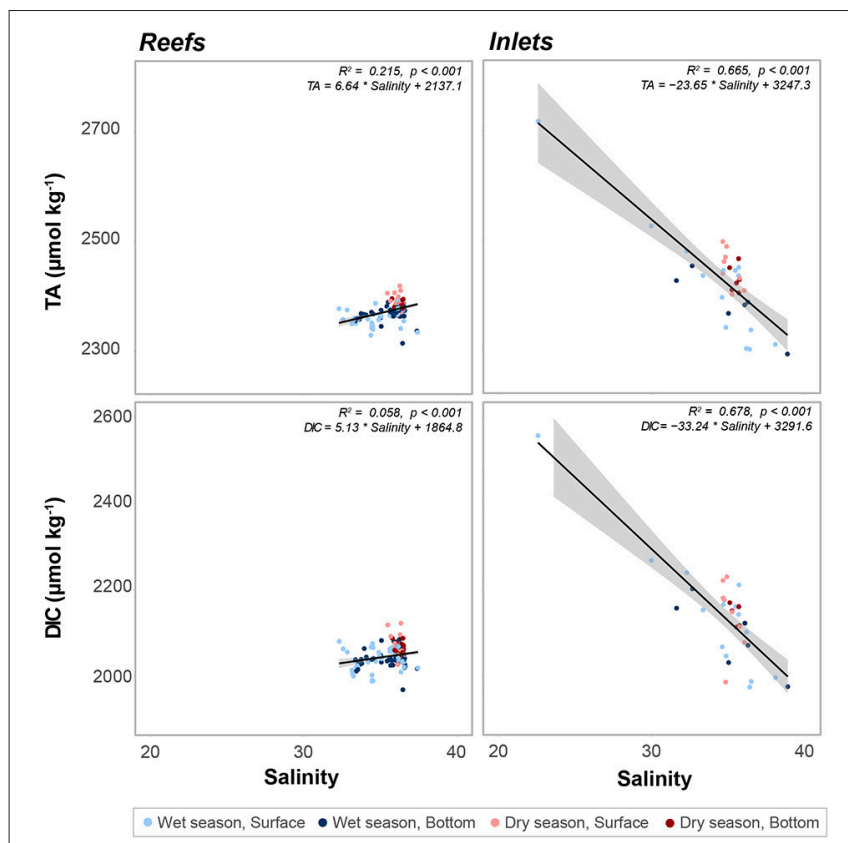

FIGURE 5 | Linear regression of total alkalinity (TA, $\mu \mathrm{mol} \mathrm{kg}{ }^{-1}$ ) as a function of salinity at reef and inlet sites. Error bars in gray, $\mathrm{R}^{2}$ and $p$ values, as well as the equation for each fitted line given for each sampling site. Data are divided into dry (red) and wet season (blue). Darker colors represent samples taken above the benthos while lighter colors represent samples taken at the surface.

to the depressed $\mathrm{pH}$ at the inlets. This is shown by the greater slope in the regression of DIC with salinity when compared to TA (Figure 5). The negative relationship of these carbonate chemistry parameters with salinity stands out as anomalous when compared with other estuarine systems throughout the wider Atlantic and Caribbean, which demonstrate a clear positive correlation between TA and salinity (Cai et al., 2010). Even in river-dominated systems with the highest TA end members, values of roughly $2,400 \mu \mathrm{mol} \mathrm{kg}{ }^{-1}$ (Mississippi River, Cai et al., 2010) have been reported, whereas here we calculate $3,247.3$ $\mu \mathrm{mol} \mathrm{kg} \mathrm{kg}^{-1}$. In this study, not only were low-salinity inlet samples high in TA and DIC relative to their high-salinity inlet counterparts, they represented extremes that exceeded values present on the more ocean-driven reefs.

Estuarine environments with high organic carbon respiration, such as salt marshes (Cai and Wang, 1998; Cai et al., 2000), mangrove habitats (Ho et al., 2017), or those with high plankton biomass (Borges and Frankignoulle, 1999) are known to export DIC. Some studies of estuarine systems have shown a breakdown in the linearity of the TA/salinity relationship at low salinity $(<2.5)$ and a steep rise over this range, but still a lower TA end member (e.g., Cai et al., 2004). Others have found a parabolic relationship, with an alkalinity peak at intermediate levels of salinity (Ho et al., 2017). Similar to data reported for inlets herein, spatial surveys of nearby Florida Bay, revealed high alkalinity, high DIC acidified waters correlated with lower salinity (Millero et al., 2001). Elevated levels of phosphate near the mangrove fringe of the Everglades indicated desorption during dissolution of $\mathrm{CaCO}_{3}$ sediments, which was likely due to oxidation of abundant organic matter resulting in a rise in $\mathrm{CO}_{2}$ and a decline in $\mathrm{pH}$ (Millero et al., 2001). These processes may also be contributing to localized acidification reported herein, as the inlets examined in this study are connected to Everglades waters, composed of carbonate sediments, and occupied by mangrove communities.

We note that the analysis of data from fixed-site time series (one per inlet) used here differs from the spatially distributed transects across ocean margins (Cai et al., 2010) or estuaries (Millero et al., 2001; Cai et al., 2004) even if those transects are repeated over time. Our data therefore represent a temporally dynamic system, with periodic low salinity fluxes correlated with high DIC, high TA water. This difference may help to explain the apparent incongruity of these data with some of the aforementioned studies because the continuum of salinity is not simply a function of steady mixing of fresh and ocean water, but rather the temporal variability in freshwater output and correlated alteration of carbonate chemistry. The relationships shown in Figure 5 are therefore likely strongly influenced by extreme events and the explicit use of calculated end members should be done with care.

The origin of this variable high TA and DIC freshwater source (ground vs. surface) cannot be determined with absolute certainty within the scope of this study. While the carbonaterich Biscayne Aquifer that covers both Miami-Dade and Broward counties is both surficial and highly porous (Back and Hanshaw, 1970; Fish and Stewart, 1991), development and extensive engineering projects have altered the natural water flow, contributing to accelerated clearance of storm water runoff, lowering the water table, and likely decreasing submarine discharge (Fish and Stewart, 1991). In support of this, Stalker et al. (2009) used geochemical tracers to determine the percent contribution of canals, precipitation, and groundwater to Biscayne Bay, which feeds both the Port of Miami and Baker's Haulover. They found that the greatest freshwater source was precipitation (53\% and 55\%, wet and dry season, respectively), followed by canals (37\% and $40 \%)$ and lastly groundwater $(10 \%$ and 5\%). While these data do not reflect processes occurring at Port Everglades, given the presumably low TA and DIC of rain water and low contribution of groundwater, elevated TA and DIC tied to salinity fluxes could potentially be linked with input from eutrophied, organic-rich freshwater canals and rivers.

Prior studies have highlighted canals as the most important source of nutrients within Biscayne Bay (Caccia and Boyer, 2007). Those feeding more northern areas of the bay have characteristically low dissolved oxygen and nutrient signatures that reflect the highly urbanized nature of the surrounding land (Caccia and Boyer, 2005, 2007). Data on the impact of nutrients to the surrounding coastal waters and coral reefs of the SEFCRI region are limited though studies suggest that nearby reef environments off of Palm Beach County are influenced by nutrient enrichment from sewage and agricultural sources (Lapointe, 1997; Finkl and Krupa, 2003). We observed higher TKN, TP, and Chlorophyll-a at inlet sites vs. offshore reefs (Table S3; Figure S2), reflecting localized 


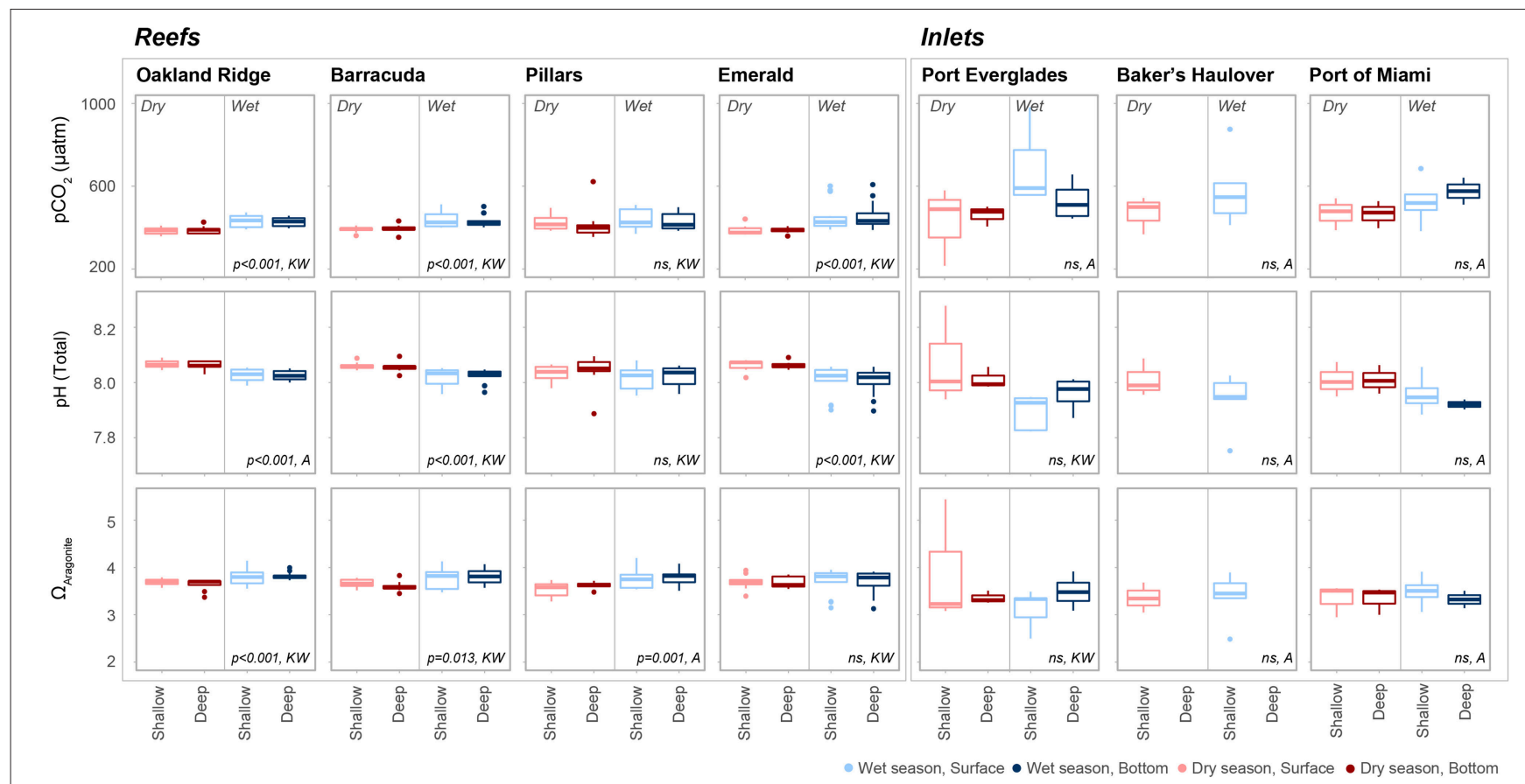

FIGURE 6 | The partial pressure of carbon dioxide ( $\mathrm{pCO}_{2}, \mu$ atm), $\mathrm{pH}$ (Total scale), and aragonite saturation state ( $\Omega$ Arag.) at each of four reef and three inlet sampling sites. Data are divided into dry (red) and wet season (blue). Darker colors represent samples taken above the benthos while lighter colors represent samples taken at the surface. $P$ values are given for significant differences as determined by ANOVA (A) or nonparametric Kruskal-Wallis (KW) tests. Non-significant $(p>0.05)$ are marked ns.

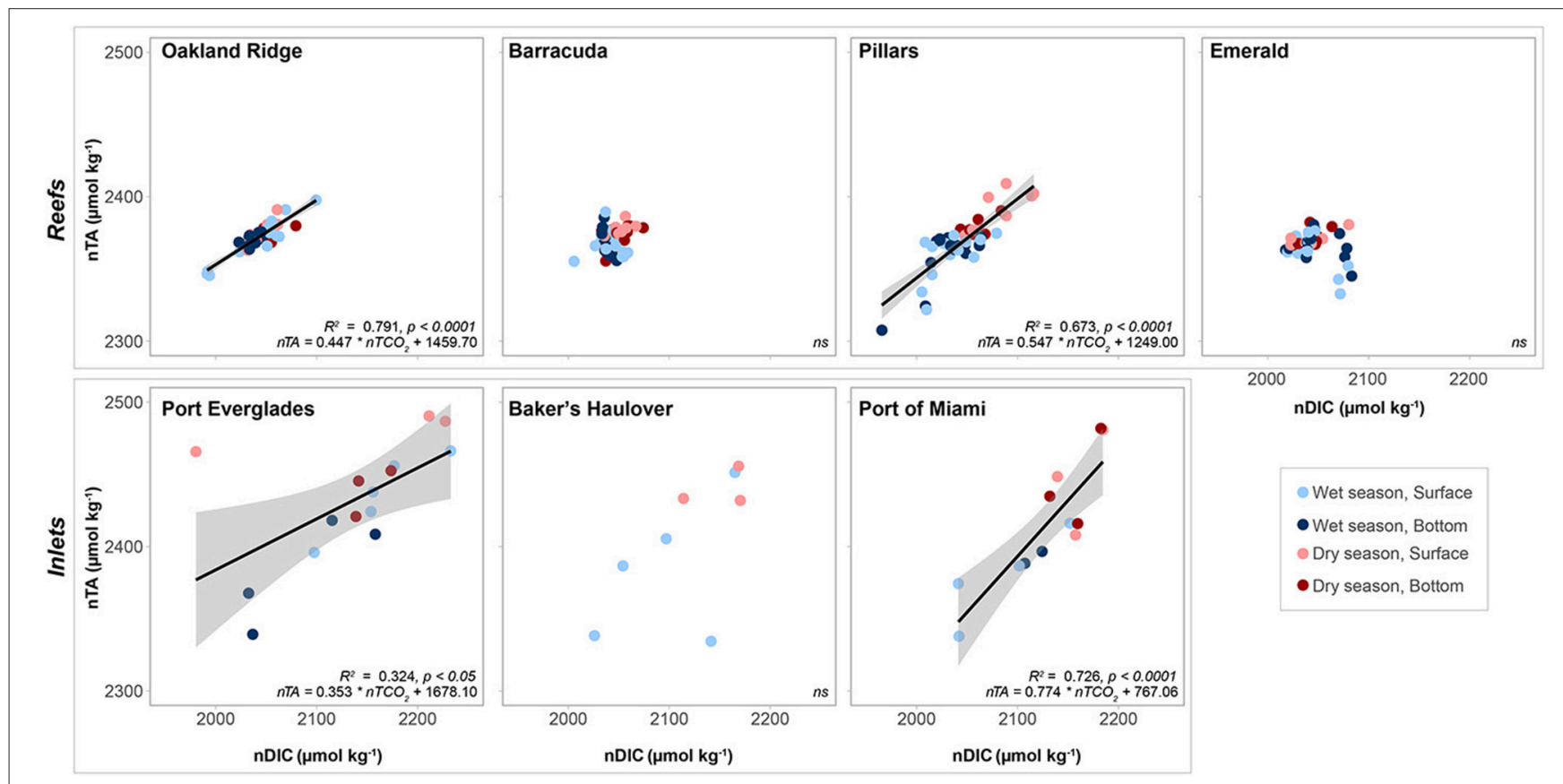

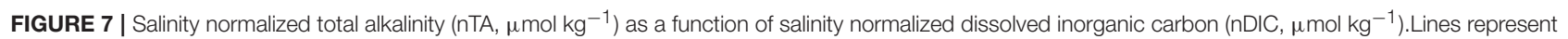
linear regression, with error bars shown in gray. $R^{2}$ and $p$ values, as well as the equation for each fitted line given for each sampling site where a significant relationship was observed. Non-significant $(p>0.05)$ are marked ns. Data are divided into dry (red) and wet season (blue) at each of four reef and three inlet sampling sites. Darker colors represent samples taken above the benthos while lighter colors represent samples taken at the surface. 
eutrophication and elevated productivity. This enrichment was correlated with hotspots of coastal acidification and support the hypothesis that eutrophication can locally elevate $\mathrm{pCO}_{2}$ (Cai et al., 2011; Wallace et al., 2014).

Coastal eutrophication should be considered when evaluating the present day and future impacts of $\mathrm{OA}$ on local carbonate chemistry. Curtailing nutrient pollution and organic matter enrichment could serve as a means for locally managing the large-scale impacts of global OA and should be incorporated into models which seek to determine the ecosystem outcomes of management strategies. Similarly, continued eutrophication or even dynamic fluctuations in nutrient output have the potential to impact carbonate chemistry monitoring efforts, and will render long-term trends due to $\mathrm{OA}$ more difficult to detect in coastal ecosystems. This is especially true in near-shore reef environments in close proximity to developed urban areas, such as those in southeast Florida, which are most heavily utilized by people.

Nutrients may also influence reef ecology more directly, via pathways outside of organic matter enrichment and localized acidification. Eutrophication can drive phase shifts from a state characterized by habitat-building corals to one dominated by less desirable macroalgae (McCook, 1999), further exacerbating the ecosystem-altering process of OA (Enochs et al., 2015). As previously noted, reefs in southeast Florida already exist in a state characterized by low coral cover and a high prevalence of benthic algae (Moyer et al., 2003). For this reason, they exist in a functionally compromised state and are potentially more prone to the multifarious and interwoven influences of eutrophication and acidification.

Other human activities have the potential to alter coastal water in the region. High turbidity was observed at the Port of Miami Inlet relative to all other collection sites and periodic spikes in turbidity were observed at Emerald Reef, which is located offshore of the inlet (S1). This elevated turbidity corresponds to a period of dredging conducted to expand the Port of Miami to be able to accommodate Panamax ships. From November 20, 2013 to March 16, 2016, roughly 4.39 million $\mathrm{m}^{3}$ of sediment and rock was removed from the channel and deposited $2.4 \mathrm{~km}$ offshore (see Figure S1 in Miller et al., 2016). The resulting sediment plumes were documented from satellites which reached nearby coral habitats (Barnes et al., 2015). During the same period, stretching into March of 2015, both TA and DIC were elevated at the Port of Miami compared to samples collected thereafter (Figure 4). The abrupt relative decline was not observed at any of the other inlet or reef sites. The pore waters of carbonate sediments, especially those high in organic matter may be high in DIC and TA due to metabolic dissolution (Andersson and Gledhill, 2013). This process can be oxygen-limited and processes which perturb and oxygenate sediment pore waters can therefore contribute to further organic matter decomposition and to greater dissolution (Andersson and Gledhill, 2013). Dredging activity may therefore act to release this high TA pore water into the above water column, as well as to further oxygenate previously buried sediments and organic matter, contributing to further dissolution. Additionally, higher water column turbidity resulting in lower light reaching the benthos, and greater metabolic stress due to direct sediment exposure may also lead to higher respiration and reduced photosynthesis, further contributing to elevated DIC (Manzello et al., 2013). Further dredging activities are planned for Port Everglades and it remains to be seen whether sediment disturbance will lead to alteration in seawater turbidity as well as carbonate chemistry parameters.

At present, inlet-driven acidification does not appear to be strongly impacting the carbonate chemistry of the nearby reef sites. While inlet carbonate chemistry was highly variable and strongly correlated with salinity, TA and DIC variation at reef sites was constrained to more subtle seasonal variation, reflecting a separation of processes driving the two site types. "Urban corals" (Heery et al., 2018) growing on anthropogenic hard substrates in the immediate vicinity of inlets are periodically experiencing acidification conditions predicted to occur in the future due to rising atmospheric $\mathrm{CO}_{2}$. The physiology and genetics of these individuals may therefore provide insight into coral resilience to $\mathrm{OA}$, though it is cautioned that dynamic $\mathrm{pH}$ fluctuations may result in different physiological responses than more-static conditions (Rivest et al., 2017; Enochs et al., 2018).

In conclusion, the seawater exiting the inlets of southeast Florida has highly variable carbonate chemistry that can include very low $\mathrm{pH}$ excursion. While reef environments revealed more characteristic seasonal fluctuations driven by biological processes, nearby inlets were periodic sources of lowsalinity, high- $\mathrm{CO}_{2}$ waters, and therefore potential sources of coastal acidification. Monitoring and management of carbonate chemistry parameters in tandem with nutrients is important going forward, along with further investigation into the degree to which inlets influence nearby reef ecosystems.

\section{AUTHOR CONTRIBUTIONS}

PRJ, SJS, and TPC collected water samples. All authors participated in analysis and manuscript preparation.

\section{FUNDING}

Field operations were funded by Florida's Department of Environmental Protection. NOAA's Coral Reef Conservation Program and Ocean Acidification Program provided funding for analysis of carbonate chemistry.

\section{ACKNOWLEDGMENTS}

We are grateful to J. Bishop, M. Doig, C. Featherstone, M. Gidley, R. Kotkowski, L. Valentino, B. Vandine, and M. Weekly for providing assistance with water collection. M. McDonald and K. Loggins provided important insights throughout manuscript preparation.

\section{SUPPLEMENTARY MATERIAL}

The Supplementary Material for this article can be found online at: https://www.frontiersin.org/articles/10.3389/fmars. 2019.00160/full\#supplementary-material 


\section{REFERENCES}

Andersson, A. J., and Gledhill, D. (2013). Ocean acidification and coral reefs: effects on breakdown, dissolution, and net ecosystem calcification. Ann. Rev. Mar. Sci. 5, 321-348. doi: 10.1146/annurev-marine-121211-172241

Aufdenkampe, A. K., Mayorga, E., Raymond, P. A., Melack, J. M., Doney, S. C., Alin, S. R., et al. (2011). Riverine coupling of biogeochemical cycles between land, oceans, and atmosphere. Front. Ecol. Environ. 9, 53-60. doi: $10.1890 / 100014$

Back, W., and Hanshaw, B. (1970). Comparison of chemical hydrogeology of the carbonate peninsulas of Florida and Yucatan. J. Hydrol. 10, 330-368. doi: 10.1016/0022-1694(70)90222-2

Banks, K. W., Riegl, B. M., Richards, V. P., Walker, B. K., Helmle, K. P., Jordan, L. K. B., et al. (2008). "The reef tract of continental Southeast Florida (MiamiDade, Broward and Palm Beach Counties, USA)," in Coral Reefs of the USA. Coral Reefs of the World, Vol. 1, eds B. M. Riegl and R. E. Dodge (Dordrecht: Springer), 175-220.

Banks, K. W., Riegl, B. M., Shinn, E. A., Piller, W. E., and Dodge, R. E. (2007). Geomorphology of the Southeast Florida continental reef tract (MiamiDade, Broward, and Palm Beach Counties, USA). Coral Reefs 26, 617-633. doi: 10.1007/s00338-007-0231-0

Barnes, B. B., Hu, C., Kovach, C., and Silverstein, R. N. (2015). Sediment plumes induced by the Port of Miami dredging: analysis and interpretation using Landsat and MODIS data. Remote Sens. Environ. 170, 328-339. doi: 10.1016/j.rse.2015.09.023

Barnes, R. T., and Raymond, P. A. (2009). The contribution of agricultural and urban activities to inorganic carbon fluxes within temperate watersheds. Chem. Geol. 266, 318-327. doi: 10.1016/j.chemgeo.2009.06.018

Bates, N., Astor, Y., Church, M., Currie, K., Dore, J., Gonaález-Dávila, M., et al. (2014). A time-series view of changing ocean chemistry due to ocean uptake of anthropogenic $\mathrm{CO}_{2}$ and ocean acidification. Oceanography 27, 126-141. doi: $10.5670 /$ oceanog.2014.16

Bates, N. R. (2007). Interannual variability of the oceanic $\mathrm{CO}_{2}$ sink in the subtropical gyre of the North Atlantic Ocean over the last 2 decades. J. Geophys. Res. 112:26. doi: 10.1029/2006JC003759

Borges, A., and Frankignoulle, M. (1999). Daily and seasonal variations of the partial pressure of $\mathrm{CO}_{2}$ in surface seawater along Belgian and southern Dutch coastal areas. J. Mar. Syst. 19, 251-266. doi: 10.1016/S0924-7963(98)00093-1

Borges, A., and Gypens, N. (2010). Carbonate chemistry in the coastal zone responds more strongly to eutrophication than to ocean acidification. Limnol. Oceanogr. 55, 346-353. doi: 10.4319/lo.2010.55.1.0346

Brake, S., Connors, K., and Romberger, S. (2001). A river runs through it: impact of acid mine drainage on the geochemistry of West Little Sugar Creek pre- and post-reclamation at the Green Valley coal mine, Indiana, USA. Environ. Geol. 40, 1471-1481. doi: 10.1007/s002540100373

Caccia, V. G., and Boyer, J. N. (2005). Spatial patterning of water quality in Biscayne Bay, Florida as a function of land use and water management. Mar. Pollut. Bull. 50, 1416-1429. doi: 10.1016/j.marpolbul.2005.08.002

Caccia, V. G., and Boyer, J. N. (2007). A nutrient loading budget for Biscayne Bay, Florida. Mar. Pollut. Bull. 54, 994-1008. doi: 10.1016/j.marpolbul.2007.02.009

Cai, W.-J., Dai, M., Wang, Y., Zhai, W., Huang, T., Chen, S., et al. (2004). The biogeochemistry of inorganic carbon and nutrients in the Pearl River estuary and the adjacent Northern South China Sea. Cont. Shelf Res. 24, 1301-1319. doi: 10.1016/j.csr.2004.04.005

Cai, W.-J., Hu, X., Huang, W.-J., Jiang, L.-Q., Wang, Y., Peng, T.-H., et al. (2010). Alkalinity distribution in the western North Atlantic Ocean margins. J. Geophys. Res. 115:C08014. doi: 10.1029/2009JC005482

Cai, W.-J., Hu, X., Huang, W.-J., Murrell, M. C., Lehrter, J. C., Lohrenz, S. E., et al. (2011). Acidification of subsurface coastal waters enhanced by eutrophication. Nat. Geosci. 4, 766-770. doi: 10.1038/ngeo1297

Cai, W.-J., Wiebe, W. J., Wang, Y., and Sheldon, J. E. (2000). Intertidal marsh as a source of dissolved inorganic carbon and a sink of nitrate in the Satilla Riverestuarine complex in the southeastern U.S. Limnol. Oceanogr. 45, 1743-1752. doi: 10.4319/lo.2000.45.8.1743

Cai, W. J., and Wang, Y. (1998). The chemistry, fluxes, and sources of carbon dioxide in the estuarine waters of the Satilla and Altamaha Rivers, Georgia. Limnol. Oceanogr. 43, 657-668. doi: 10.4319/lo.1998.43.4.0657
Crook, E. D., Potts, D., Rebolledo-Vieyra, M., Hernandez, L., and Paytan, A. (2011). Calcifying coral abundance near low-pH springs: implications for future ocean acidification. Coral Reefs 31, 239-245. doi: 10.1007/s00338-0110839-y

Cyronak, T., Andersson, A. J., Langdon, C., Albright, R., Bates, N. R., Caldeira, K., et al. (2018). Taking the metabolic pulse of the world's coral reefs. PLoS ONE 13:e0190872. doi: 10.1371/journal.pone. 0190872

Dickson, A. G. (1990). Thermodynamics of the dissociation of boric acid in synthetic seawater from 273.15 to 318.15 K. Deep Sea Res. 37, 755-766. doi: 10.1016/0198-0149(90)90004-F

Dickson, A. G., and Millero, F. J. (1987). A comparison of the equilibrium constants for the dissociation of carbonic acid in seawater media. Deep Sea Res. 34, 1733-1743. doi: 10.1016/0198-0149(87)90021-5

Dickson, A. G., Sabine, C. L., and Christian, J. R. (2007). Guide to Best Practices for Ocean $\mathrm{CO}_{2}$ Measurements. Sydney, BC: PICES Special Publication.

Duarte, C. M., Hendriks, I. E., Moore, T. S., Olsen, Y. S., Steckbauer, A., Ramajo, L., et al. (2013). Is ocean acidification an open-ocean syndrome? Understanding anthropogenic impacts on seawater pH. Estuaries Coast 36, 221-236. doi: 10.1007/s12237-013-9594-3

Enochs, I., Manzello, D., Donham, E., Kolodziej, G., Okano, R., Johnston, L., et al. (2015). Shift from coral to macroalgae dominance on a volcanically acidified reef. Nat. Clim. Chang. 5, 1083-1089. doi: 10.1038/nclimate2758

Enochs, I. C., Manzello, D. P., Jones, P. J., Aguilar, C., Cohen, K., Valentino, L., et al. (2018). The influence of diel carbonate chemistry fluctuations on the calcification rate of Acropora cervicornis under present day and future acidification conditions. J. Exp. Mar. Biol. Ecol. 506, 135-143. doi: 10.1016/j.jembe.2018.06.007

EPA (1993a). Method 351.2, Revision 2.0: Determination of Total Kjeldahl Nitrogen by Semi-Automated Colorimetry. Cincinnati, OH: U.S. Environmental Protection Agency, Environmental Monitoring Systems Laboratory, Office of Research and Development, US EPA.

EPA (1993b). Method 365.1, Revision 2.0: Determination of Phosphorus by Semi-Automated Colorimetry. Cincinnati, OH: U.S. Environmental Protection Agency, Environmental Monitoring Systems Laboratory, Office of Research and Development, US EPA.

EPA (1997). In vitro Determination of Chlorophyll a and Pheophytin a in Marine and Freshwater Algae by Fluorescence. Cincinnati, OH: U.S. Environmental Protection Agency, National Exposure Research Laboratory, Office of Research and Development, US EPA.

Fabricius, K. E., Langdon, C., Uthicke, S., Humphrey, C., Noonan, S., De'ath, G., et al. (2011). Losers and winners in coral reefs acclimatized to elevated carbon dioxide concentrations. Nat. Clim. Chang. 1, 165-169. doi: $10.1038 /$ nclimate 1122

Fabry, V. J., Seibel, B. A., Feely, R. A., and James, O. C. (2008). Impacts of ocean acidification on marine fauna and ecosystem processes. ICES J. Mar. Sci. 65, 414-432. doi: 10.1093/icesjms/fsn048

Feely, R. A., Sabine, C. L., Hernandez-Ayon, J. M., Ianson, D., and Hales, B. (2008). Evidence for upwelling of corrosive "acidified" water onto the continental shelf. Science 320, 1490-1492. doi: 10.1126/science.1155676

Finkl, C. W., and Krupa, S. L. (2003). Environmental impacts of coastal-plain activities on sandy beach systems: hazards, perception and mitigation. J. Coast. Res. $132-150$

Fish, J. E., and Stewart, M. (1991). Hydrogeology of the Surficial Aquifer System Dade County, Florida. Report 90-4108, US Geological Survey.

Friis, K., Körtzinger, A., and Wallace, D. W. R. (2003). The salinity normalization of marine inorganic carbon chemistry data. Geophys. Res. Lett. 30:1085. doi: 10.1029/2002GL015898

Gagliano, M., McCormick, M. I., Moore, J. A., and Depczynski, M. (2010). The basics of acidification: baseline variability of $\mathrm{pH}$ on Australian coral reefs. Mar. Biol. 157, 1849-1856. doi: 10.1007/s00227-010-1456-y

Goldberg, W. M. (1973). The ecology of the coral-octocoral communities off the southeast Florida coast: geomorphology, species composition, and zonation. Bull. Mar. Sci. 3, 465-488.

Heery, E. C., Hoeksema, B. W., Browne, N. K., Reimer, J. D., Ang, P. O., Huang, D., et al. (2018). Urban coral reefs: degradation and resilience of hard coral assemblages in coastal cities of East and Southeast Asia. Mar. Pollut. Bull. 135, 654-681. doi: 10.1016/j.marpolbul.2018.07.041 
Ho, D. T., Ferrón, S., Engel, V. C., Anderson, W. T., Swart, P. K., Price, R. M., et al. (2017). Dissolved carbon biogeochemistry and export in mangrovedominated rivers of the Florida Everglades. Biogeosciences 14, 2543-2559. doi: 10.5194/bg-14-2543-2017

Hofmann, G. E., Smith, J. E., Johnson, K. S., Send, U., Levin, L. A., Micheli, F., et al. (2011). High-frequency dynamics of ocean pH: a multiecosystem comparison. PLOS ONE 6:e28983. doi: 10.1371/journal.pone. 0028983

Johns, G. M., Leeworthy, V. R., Bell, F. W., and Bonn, M. A. (2003). Socioeconomic Study of Reefs in Southeast Florida (Final Report). Hollywood, FL: Hazen and Sawyer, Environmental Engineers and Scientists.

Lantz, C. A., Atkinson, M. J., Winn, C. W., and Kahng, S. E. (2013). Dissolved inorganic carbon and total alkalinity of a Hawaiian fringing reef: chemical techniques for monitoring the effects of ocean acidification on coral reefs. Coral Reefs 33, 105-115. doi: 10.1007/s00338-013-1082-5

Lapointe, B. E. (1997). Nutrient thresholds for bottom-up control of macroalgal blooms on coral reefs in Jamaica and southeast Florida. Limnol. Oceanogr. 42, 1119-1131. doi: 10.4319/lo.1997.42.5_part_2.1119

Le Quéré, C., Andrew, R. M., Friedlingstein, P., Sitch, S., Pongratz, J., Manning, A. C., et al. (2018). Global carbon budget 2017. Earth Syst. Sci. Data 10, 405-448. doi: 10.5194/essd-10-405-2018

Lewis, E., and Wallace, D. (1998). Program Developed for $\mathrm{CO}_{2}$ System Calculations. Oak Ridge, TN: ORNL/CDIAC.

Lighty, R. G., Macintyre, I. G., and Stuckenrath, R. (1978). Submerged early Holocene barrier reef south-east Florida shelf. Nature 276, 59-60. doi: $10.1038 / 276059 \mathrm{a} 0$

Lirman, D., and Cropper, W. P. (2003). The influence of salinity on seagrass growth, survivorship, and distribution within Biscayne Bay, Florida: field, experimental, and modeling studies. Estuaries 26, 131-141. doi: 10.1007/BF02691700

Manzello, D., Enochs, I., Musielewicz, S., Carlton, R., and Gledhill, D. (2013). Tropical cyclones cause $\mathrm{CaCO}_{3}$ undersaturation of coral reef seawater in a high- $\mathrm{CO}_{2}$ world. J. Geophys. Res. Oceans 118, 5312-5321. doi: $10.1002 /$ jgrc.20378

Manzello, D. P. (2010). Ocean acidification hot spots: spatiotemporal dynamics of the seawater $\mathrm{CO}_{2}$ system of eastern Pacific coral reefs. Limnol. Oceanogr. 55:239. doi: 10.4319/lo.2010.55.1.0239

Manzello, D. P., Enochs, I. C., Melo, N., Gledhill, D. K., and Johns, E. M. (2012). Ocean acidification refugia of the Florida Reef Tract. PLoS ONE 7:e41715. doi: 10.1371/journal.pone.0041715

McCook, L. J. (1999). Macroalgae, nutrients and phase shifts on coral reefs scientific issues and management consequences for the Great Barrier. Coral Reefs 18, 357-367. doi: 10.1007/s003380050213

Mehrbach, C., Culberson, C. H., Hawley, J. E., and Pytkowicz, R. M. (1973). Measurement of the apparent dissociation constants of carbonic acid in seawater at atmospheric pressure. Limnol. Oceanogr. 18, 897-907. doi: 10.4319/lo.1973.18.6.0897

Miller, M. W., Karazsia, J., Groves, C. E., Griffin, S., Moore, T., Wilber, P., et al. (2016). Detecting sedimentation impacts to coral reefs resulting from dredging the Port of Miami, Florida USA. PeerJ 4:e2711. doi: 10.7717/peerj.2711
Millero, F. J., Hiscock, W. T., Huang, F., Roche, M., and Zhang, J. Z. (2001). Seasonal variation of the carbonate system in Florida Bay. Bull. Mar. Sci. $68,101-123$.

Moyer, R. P., Riegl, B., Banks, K., and Dodge, R. E. (2003). Spatial patterns and ecology of benthic communities on a high-latitude South Florida (Broward County, USA) reef system. Coral Reefs 22, 447-464. doi: 10.1007/s00338-003-0334-1

Oh, N.-H., and Raymond, P. A. (2006). Contribution of agricultural liming to riverine bicarbonate export and $\mathrm{CO}$ 2sequestration in the Ohio River basin. Global Biogeochem. Cycles 20:GB3012. doi: 10.1029/2005GB002565

Precht, W. F., and Aronson, R. B. (2004). Climate flickers and range shifts of reefcorals. Front. Ecol. Environ. 2, 307-314. doi: 10.1890/15409295(2004)002[0307:CFARSO]2.0.CO;2

Price, N. N., Martz, T. R., Brainard, R. E., and Smith, J. E. (2012). Diel variability in seawater $\mathrm{pH}$ relates to calcification and benthic community structure on coral reefs. PLoS ONE 7:e43843. doi: 10.1371/journal.pone.0043843

$\mathrm{R}$ Team (2008). R: A Language and Environment for Statistical Computing. Vienna: R Foundation for Statistical Computing.

Raymond, P. A., and Cole, J. J. (2003). Increase in the export of alkalinity from North America's largest river. Science 301, 88-91. doi: 10.1126/science.1083788

Rivest, E. B., Comeau, S., and Cornwall, C. E. (2017). The role of natural variability in shaping the response of coral reef organisms to climate change. Curr. Clim. Chang. Rep. 3, 271-281. doi: 10.1007/s40641-017-0082-x

RStudio Team (2015). RStudio: Integrated Development for R. Boston, MA: RStudio, Inc.

Shaw, E. C., and McNeil, B. I. (2014). Seasonal variability in carbonate chemistry and air-sea $\mathrm{CO}_{2}$ fluxes in the southern Great Barrier Reef. Mar. Chem. 158, 49-58. doi: 10.1016/j.marchem.2013.11.007

Silbiger, N. J., Guadayol, Ò., Thomas, F. I. M., and Donahue, M. J. (2014). Reefs shift from net accretion to net erosion along a natural environmental gradient. Mar. Ecol. Prog. Ser. 515, 33-44. doi: 10.3354/meps10999

Stalker, J. C., Price, R. M., and Swart, P. K. (2009). Determining spatial and temporal inputs of freshwater, including submarine groundwater discharge, to a subtropical estuary using geochemical tracers, Biscayne Bay, South Florida. Estuaries Coast 32, 694-708. doi: 10.1007/s12237-009-9155-y

Wallace, R. B., Baumann, H., Grear, J. S., Aller, R. C., and Gobler, C. J. (2014). Coastal ocean acidification: the other eutrophication problem. Estuar. Coast. Shelf Sci. 148, 1-13. doi: 10.1016/j.ecss.2014.05.027

Conflict of Interest Statement: The authors declare that the research was conducted in the absence of any commercial or financial relationships that could be construed as a potential conflict of interest.

Copyright $\odot 2019$ Enochs, Manzello, Jones, Stamates and Carsey. This is an openaccess article distributed under the terms of the Creative Commons Attribution License (CC BY). The use, distribution or reproduction in other forums is permitted, provided the original author(s) and the copyright owner(s) are credited and that the original publication in this journal is cited, in accordance with accepted academic practice. No use, distribution or reproduction is permitted which does not comply with these terms. 